\title{
An analysis of the determinants of failure processes in UK SMEs.
}

MAKROPOULOS, A., WEIR, C. and ZHANG, X.

2020 


\title{
An analysis of the determinants of failure processes in UK SMEs
}

\begin{abstract}
Purpose - This paper has two purposes. First, it evaluates the extent to which different failure processes are present in failed UK SMEs, by considering non-financial metrics including director characteristics, in addition to the financial ones. Second, it analyses the determinants of the transition to failure in relation to the different failure processes that have been identified.
\end{abstract}

Design/methodology/approach - The study is based on a sample of failed UK SMEs. The data covers financial ratios, board characteristics, the macroeconomic environment, sectoral details and regional information. First, failure processes are identified using a combination of factor analysis and cluster analysis. Second, the determinants of firms' transition to failure for the whole sample and in the individual failure clusters are analysed using panel data analysis.

Findings - Four different firm failure processes were identified. Director characteristics differ between firm failure processes. We find evidence that director characteristics including director age and board gender structure, affect the transition to failure of UK SMEs. We also find that different factors affect the different failure processes.

Originality/value - The paper is the first to analyse the reasons for failure of UK SMEs in the firm failure process context by considering non-financial metrics such as the characteristics of the firms' directors. In addition the paper also identifies a number of different determinants that affect the various failure processes. This finding is important because it suggests that policies designed to reduce the incidence of firm failure should take account of the different failure processes.

Keywords- Firm failure process, SME, Financial variables, board structure.

\section{Paper type Research paper}




\section{Introduction}

Small and Medium sized Enterprises (SMEs) account for $99.9 \%$ of the UK's private sector businesses and for over $60 \%$ of the private sector employment in the UK (FSB, 2019). As a result, employees, suppliers and other stakeholders incur significant loss when SMEs enter liquidation.

Whilst there has been significant research looking to predict firm failure or to identify firms that are about to fail from a population of eventually failed and non-failed firms (eg Altman, 1968; Pindado and Rodrigues, 2004; Altman et al., 2010), much less attention has been given to the analysis of firm failure processes, something which this paper addresses. First, the paper identifies a number of firm failure processes and second, it examines the determinants of the transition to failure for each of these processes.

The terminology used for describing the experience of a firm that ultimately fails has changed over time. For example, Argenti (1976), in his seminal work where the term 'failure process' was first used (interchangeably with the term failure paths), explained that there is a failure time span that occurs before a firm fails, as generally firms do not fail suddenly. This time span may take years. The first part of the time span starts with managerial weaknesses that are associated with the skills, experience and characteristics of a firm's directors. The second part of the time span includes management errors and mistakes (driven by the weaknesses of the first part). The third part of the timespan includes the symptoms of failure which include (weak) financial characteristics. In Argenti's (1976) work, the sequence of these three time span characteristics are collectively called 'failure processes'. More recent literature also uses the term 'failure process' (see for example, Ooghe, 2008; Lukason, 2017; Laitinen, 2014). Lukason (2016, p.13) defines the 'failure process' as "a pathway in a firm's lifecycle ending with bankruptcy which, using non-financial variables depicts why, and financial variables how, a firm becomes bankrupt". Lukason et al., (2016, p.1967) argues that "[the] decline process and failure process [of a firm] can be seen as synonyms if both end with bankruptcy". Lukason and Laitinen, (2016, p.310) in addition argue that "Studies focusing on firm failure processes offer an insight in which different ways firms collapse". These studies use Argenti's (1976) definition to identify 
different firm failure processes. The key characteristics of firms' directors typically come first and the financial issues come typically last in the firm failure process. For this reason, some of these studies look only at one part of the firm failure process (usually the financial characteristics of the firms) to define the failure process a firm belongs to.

We reflect this by using the 'failure process' term in the same way. A firm failure process occurs and evolves over a time span and is the result of a combination of underlying reasons, such as directors' characteristics, that have been part of the firm for a number of years. These lead to mistakes that lead to a deterioration in a firm's finances and eventually to failure. As such, by analysing the alternative firm failure processes, we consider the directors' characteristics and the financial characteristics that firms have over a number of years prior to their failure. The firm failure process literature contends that firms do not fail as the consequence of a single exogenous event but rather experience long term firm-specific problems which ultimately lead to its failure. Further, failed firms that shared a number of similar board and financial characteristics in the years prior to failure can be said that belong to the same firm failure process.

It is also the case that there are a number of different failure processes that different firms may experience prior to their failure and these processes are effectively the firms' paths to liquidation, (Argenti, 1976). For example, according to Argenti (1976) the first firm failure process identified is that of a relatively new firm which never achieves good performance, does not become successful and fails; the second failure process is that of a rapid growth firm that fails because the entrepreneur cannot deal with the sudden success of the firm; the third failure process is the case of an old firm that performed well for a period before its performance deteriorated, eventually resulting in failure.

Studies investigating and comparing the existence of firm failure processes remain rather limited since Argenti (1976) and have generally focused on the corporate sector (eg. Hambrick and D'Aveni, 1988; D'Aveni, 1989). In the SME context, there is evidence of failure processes in different countries (eg. Laitinen et al, 2014; Laitinen and Lukason, 2015; Lukason and Laitinen, 2016) and within specific sectors, such as manufacturing (Lukason et al., 2016). These studies concentrated on the role of financial performance in the failure of firms. 
This study analyses a sample of failed UK SMEs and identifies a number of failure processes that exist among failed UK SMEs. First, the study adds on the existing literature by also considering non-financial, firm-specific characteristics, such as a firm's age and their directors' characteristics in the identification of the firm failure processes. These characteristics have been omitted from the previous quantitative firm failure process studies.

Second, the study adds to the existing literature by evaluating the factors that determine the firms' transition to failure for each identified firm failure process. The firm-specific characteristics that are used in the first part of the analysis to identify the alternative firm failure processes are changing over-time as the firms are moving towards their failure. The firm specific characteristics of each firm failure process are similar among the firms in that process. However, these characteristics do not necessarily have a causal relationship with the firms' failure. As a result, this study makes a distinction between the characteristics of the firm failure processes, which are common, firm-specific characteristics associated with each firm failure process, and the determinants of firms' transition to failure which are actually the characteristics that have a causal effect to firms' failure. The latter can be firm-specific or from the wider economic and business environment.

The study also considers firm failure processes in the context of UK regions, by investigating the extent to which firm failure processes are concentrated in particular UK regions.

Previous firm failure process studies have identified a number of firm-specific characteristics that characterise the alternative firm failure processes but have not analysed the determinants that are statistically significant drivers of the firms' transition towards failure for each of the identified firm failure processes. As a result, whilst the existing literature has identified firm-specific characteristics that characterise the alternative firm failure processes, it is not clear which of these characteristics are determinants of the firms' transition to failure in any of the alternative firm failure processes. These elements are assessed for the first time in this quantitative study, specifically for the UK SMEs. 
Third, the study bridges the gap between analysing firms in financial distress and liquidated firms in isolation. Some studies consider financial distress as indicating firm failure in its own right (Jahur and Quadir, 2012; Šarlija and Jeger, 2011). However, studies that consider liquidation as firm failure tend not to include financial distress as an interim stage (Altman and Sabato, 2007; Baixauli and Módica-Milo, 2010). This paper includes the status of financial distress as an interim stage of firms' transition to failure so as to analyse the full process of failure from a firm being healthy, to becoming financially distressed and to finally liquidate.

The next section presents the literature review and hypotheses. This is followed by the methodology and data section. The results are then discussed and finally conclusions are drawn.

\section{Literature Review and Hypotheses}

Firm failure processes are present between firms that share similar characteristics a number of years prior to their failure. The theory behind the firm failure process research is that not all the firms that fail behave in the same way before their failure. Therefore, depending on the firm-specific characteristics and their development across a number of years prior to their failure, a number of alternative firm failure processes can be identified (Laitinen, 1991). Firm failure process studies have been both qualitative (see for example Argenti, 1976; Ooghe and Prijcker, 2008) and quantitative in nature (see for example Laitinen, 1991; Laitinen et al., 2014; Lukason and Laitinen, 2016). Firm-specific characteristics such as the characteristics of firms' directors, including the entrepreneur, and their ability to adapt to change have been historically identified as particularly relevant factors to distinguish between alternative firm failures processes, particularly in the qualitative literature (see for example Argenti, 1976). In addition to Argenti's (1976) analysis of the alternative profile of firm directors or entrepreneurs that can be associated with certain firm failure processes, the (potentially changing) priorities of the small firm directors, or of the entrepreneurs and their prior experiences, have also been identified as potential indicators of firm failure (Khelil, 2016; Politis and Gabrielsson, 2009; Mueller and Shepherd, 2014). Moreover, firm-specific characteristics such as the age of the firm, its growth and its financial characteristics have all led to distinct firm failure processes (Argenti, 1976, Ooghe and Prijcker, 2008). 
There is evidence that different failure processes persist across countries. Similar firm failure processes have been identified in a number of studies involving different countries. For example, studies have identified between 3 and 6 failure processes in countries such as the United Kingdom, Finland, Belgium, Croatia, Czech Republic, Estonia, Spain, Italy, Germany, Sweden, Ireland, France, and the United States, (Laitinen et al, 2014; Laitinen and Lukason, 2014; Lukason and Laitinen, 2016).

Consistent with the presence of firm failure processes found in a number of studies, we hypothesise that:

\section{H1: Failed UK SMEs experienced different firm failure processes}

Financial ratios have commonly been used in quantitative studies literature to distinguish between alternative firm failure processes (Laitinen, 1991; Lukason et al, 2016). This work is partly informed by wider firm failure studies (including firm failure prediction) that have traditionally used financial ratios as predictors of a firm's propensity to fail (Altman, 1968; Altman and Sabato, 2007). As such, the literature offers a wide range of financial ratios that appear to capture the basic dimensions of the financial position of the firm. Whilst there is not a universal agreement on which financial ratios are the best to discriminate between firm failure processes, financial characteristics such as liquidity, profitability and leverage of the firm have been shown to be significant characteristics of the alternative firm failure processes. In addition, the basic dimensions of liquidity, profitability and leverage of the firm have been shown to be significant determinants of firms' failure. As a consequence, a number of financial ratios that represent the basic dimensions of firms' liquidity, profitability and leverage have been proposed in a number of studies related to firm failure process and the wider firm failure area.

First, the Return on Investment ( $\mathrm{ROI}$ ) is a profitability ratio that measures the return earned by a firm in a period. It is defined as profit (loss) before tax, divided by total assets (Robinson et al., 2009). It has been used by Laitinen et al., (2014), Altman et al., (2010) and Pindado and Rodrigues (2004). The rationale for using the ratio is that firms should provide sufficient returns to their owners in order to remain viable. 
Second, the growth rate in total assets is defined as the year-on-year percentage growth in a firm's total assets. Its inclusion is consistent with Laitinen et al (2014) and Argenti (1976). Growth rate has been one of the fundamental drivers of Argenti's (1976) failure trajectories.

Third, the Net Sales to Total Assets (NSTA) follows Laitinen (1991) and Altman (1968). This is a capital turnover ratio that demonstrates a firm's ability to generate sales from the given firm's assets (Altman, 1968).

Fourth, the Cash flow to sales ratio (CFTS) has been one of Laitinen et al (2014) ratios and one of the first financial ratios that Beaver (1966) proposed. The reason for including the CFTS ratio is that a cash flow ratio shows the ability of the firm to build a cash buffer against any variations of cash inflows and outflows, and therefore the solvency of the firm can be defined in terms of the probability that this buffer may be insufficient leaving the firm unable to pay for its obligations (Beaver, 1966).

Fifth, the Total Liabilities to Total Assets directly measures the total debt of a firm compared to its total assets. Theory suggests that a firm's indebtedness is a determinant of a firm's failure (Appiah, 2013).

Sixth, the Quick ratio is a measure of a firm's liquidity, Deakin (1972), Laitinen (1992) and Pindado and Rodrigues (2004). The quick ratio considers the cash available in a firm and the accounts receivable divided by the current liabilities of the firm.

Seventh, the Quick Assets to Current Assets reflects the working capital of the firm and has been used by Altman et al (2010). Eight the Trade Credit as a proportion of Total Liabilities is a measure of trade credit (as opposed to bank credit) as a percentage of the total debt of the firm. The rationale for including the TCTL ratio is to control for the usage of trade credit that firms use between countries as this is a source of credit that small firms rely on when bank credit is not available to them (Altman et al., 2010).

As shown above, the current literature provides evidence that the financial ratios discussed above are determinants of firms' failure when failed and non-failed firms are analysed. The quantitative firm failure process literature shows that financial ratios can be used as tools to identify the alternative firm failure processes in a population of failed only firms (Laitinen, 1991; Laitinen et al., 2014; Lukason et al., 2016; Lukason and Laitinen, 2019). However, these determinants of firms' failure have 
not been tested within the context of the alternative firm failure processes that may exist in UK SMEs. Therefore, the firm failure process literature provides little evidence on whether the financial ratios that characterise the alternative firm failure processes are also statistically significant determinants of firms' transition to failure. As such, one can consider the hypothesis in the population of failed UK firms, within the context of firms' failure process and test the hypothesis that financial ratios are not only being characteristics of the alternative firm failure processes, but also determinants of firms' transition to failure in these processes. As such we hypothesise that:

H2: The financial symptoms of failure differ between UK SMEs' failure processes and are determinants of firms' transition to failure.

The experience of the directors and the gender diversity of the board are key factors that influence a firm's survival given the human and social capital they contribute to the board (Adams and Ferreira, 2009; Wilson et al., 2014). In addition, the management of the firm, including directors' characteristics, is frequently associated with firms' failure (Parker et al., 2002; Bennett and Robson, 2004; Daily et al., 2003). Despite Argenti's (1976) focus on the entrepreneur and the characteristics of firms' directors in the alternative firm failure processes he proposed, there has been little analysis of the role played by these characteristics in the alternative firm failure processes in quantitative studies involving SMEs.

Nevertheless, evidence from the wider SMEs literature has identified that the firm's management can determine a firm's direction. For example, a lack of managerial adaptability to a changing business and economic environment (Jumpponen et al., 2008) and general managerial capability (Ma and Lin, 2010) have been found to affect SMEs' survival. The experience of board members, measured by the number of directors, affects firms' survival due to the increased dimension of human and social capital (Adams and Ferreira, 2009; Wilson et al., 2014). Additionally, firms whose directors are older are associated with a reduced propensity for failure (see for example Nafziger and Terrell, 1996) given that managerial experience is positively associated with age. Likewise, management heterogeneity, especially in terms of 
gender diversity, has been associated with a reduced risk of failure (Adams and Ferreira, 2009).

A number of studies from the wider quantitative firm failure literature have identified directors' characteristics as determinants of firms' failure. Firms' boards need a variety of skills, information, and experiences to exercise effective monitoring and management of the firm, Hillman and Dalziel (2003). Given the complexities associated with obtaining extensive quantitative data to measure firm' directors experience, ability and access to business and social networks and the diversity of the board, particularly for SMEs, a number of proxies are used in the literature.

i) Measuring the Directors' Experience: Age of directors

The age (Avg_dir_age) can be viewed as a proxy for managerial experience (Gray and Nowland, 2013) and also as a proxy of a person's propensity for risk taking (Hermann and Datta, 2005). A number of studies have identified that younger directors are more likely to be risk takers (Horváth and Spirollari, 2012) whilst older managers are more risk-averse (Hambrick and Mason, 1984). In firm failure studies, directors' age has been used as a proxy of the experience of the management of the firm in a number of studies (Platt and Platt, 2012; Wilson and Altanlar, 2013). A reduced average age of directors in SME boards has been associated with an increased propensity for failure (Wilson and Altanlar, 2013).

ii) Measuring the Directors' Knowledge and Networks: The Number of directors

The number of directors of a firm, has been used as a proxy for the management's ability to direct and to effectively control the firm (Bennett and Robson, 2004; Daily et al., 2002). It therefore reflects the breadth of knowledge and business and social networks of the board members. The presence of women on the board of directors is associated with reduced risk of insolvency (Adams and Ferreira, 2009; Wilson et al., 2013) at least in newly incorporated SMEs. This is because women are regarded as more risk aware (Adams and Funk, 2012). As such, a number of proxies have been used in the literature to reflect board characteristics.

The number of directors ("Total_Dir_Nr") has been used as a proxy the for the social and human capital, the knowledge and range of business and social networks of the board in line with evidence in a number of studies (see for example Zhao and Aram 1995; Watson, 2007). 
iii) Measuring Directors' Diversity: Number of Female Directors

Firms with more diverse board members have more access to resources that help to reduce external dependency, diminish uncertainty, and improve reputation (Hillman and Dalziel 2003). Such findings are usually associated with human capital theory and evidence from social psychology. Human capital theory predicts that the performance of directors is affected by board diversity as a result of the diverse and unique human capital that each individual possesses (Isidro and Sobral, 2015). Social psychology recognises that diversity on the board could have positive or negative effects depending on the dynamics of the board (Westphal and Milton 2000). Some evidence suggests that minority directors in boards, such as female directors, stimulate divergent thinking and motivate other directors to consider a wider range of potential solutions (Moscovici and Faucheux 1972; Nemeth, 1986). In addition, Adams and Funk (2009) suggest that female directors embrace values that lead to ethical decisions more than male directors. The number of female directors (female_nr) has been used as an indicator of board gender diversity in a number of studies. These studies found that the presence of gender diversity on the board (measured by the number and/or the existence of female directors) has been associated with increased firm performance and profitability (Burke, 2000; Isidro and Sobral, 2015; Shehata et al., 2017) as well as with fewer firm failures - even in the small firms (see for example Altanlar and Wilson, 2013).

Whilst there is evidence in the qualitative firm failure process literature showing that the directors' characteristics differ between alternative firm failure processes (Argenti, 1976) there is no quantitative research that analyses the role of director characteristics on firm failure processes. However, there is evidence from wider firm failure studies show that directors' characteristics are determinants of firms' failure. These include entrepreneurs' experience, entrepreneurial aspirations and personal priorities that eventually inform entrepreneurs' attitudes towards failure (Khelil, 2016; Politis and Gabrielsson, 2009). Extending the findings from the wider firm failure literature to UK firms' failure processes, leads to the following hypothesis: 
H3: The director characteristics of UK SMEs differ in alternative firm failure processes and are determinants of firms' transition to failure.

There is also evidence that the age of a firm plays an important role in firm failure. Young firms may be defined as being less than 10 years old (Wagner, 2004; Davidsson, 2003). Firm age has been identified as having an influence on firm failures (see for example Falck, 2007; Altman et al., 2010), with younger firms being perceived as riskier in terms of their propensity to fail. Argenti (1976) reported that one of his firm failure processes included the young firm that never succeed whilst another one included old firms whose performance had gradually deteriorated. Likewise, Lukason et al., (2016) reported that the number of firm failure processes varies with firms' age, when analysing young manufacturing firms in Europe. Consistent with the limited evidence on the age of the firms in alternative firm failure studies, the following hypothesis is proposed:

H4: Firm age differs in the alternative firm failure processes of the UK SMEs and is a determinant of firms' transition to failure.

In the context of firm failure, there has been evidence that the economic and business environment in which firms operate, have also been associated with firm failure. First, the wider state of the economy, measured for example by GDP growth (Everett and Watson, 1998; Bunn and Redwood, 2003; Liu, 2009, Tsoukas 2011) affects firm failure with lower economic growth having a positive effect on firm failure. Second, credit availability for SMEs was found to be important, (Berger and Udell, 2002). This is relevant for this study because it includes the recent financial crisis period which was characterised by reduced credit availability, especially for small firms (Gaiotti, 2011). Likewise, the business competitive environment can be an additional factor that affects firms' financial distress and failure. Potential changes in the competitive business environment at regional level where many SMEs operate may affect business failures. For example, competition between firms within UK regions as the result of new firms entering a regional market, may have an adverse effect in already existing firms and may therefore result in increased failures or business exits (Love, 1996). This is consistent with evidence that regions with high 
increases in their business populations experience higher business exits (Lane and Schary, 1991; Keeble and Walker, 1994; He and Yung, 2016). As a result, one can form the following hypothesis:

H5: Economic and business environment conditions are significant determinants of firms' transition to failure

\section{Data and Methodology}

\section{Sample, Data and Variables}

This study uses firm-specific data obtained from Bureau van Dijk's Amadeus database. The database covers all SMEs that went into liquidation during the period 2004 to 2013 in the UK. The original dataset consisted of 1,025 UK failed firms, whose turnover, total assets and number of employees were consistent with the UK Companies Act (2006) definition of an SME was gathered. The sample included firms with a turnover of less than $£ 22.8 \mathrm{~m}$, total assets of less than $£ 11.4 \mathrm{~m}$ and fewer than 250 employees. Subsequently firms with missing values in any of the financial ratios and in the directors' characteristics that were required for the analysis and with less than 7 years of data were excluded from the sample. This resulted in a final sample of 979 failed UK SMEs covering all UK regions. These firms went into liquidation during the period 2004 to 2013 , an era that covers the recent financial crisis. There are 7,041 firm-year observations in the sample. Non-firm-specific data relating to the business and economic environment are taken from the World Bank Open Data, (https://data.worldbank.org/indicator/) webpage.

The sample is an unbalanced panel where firms are removed from the dataset after they fail. The definition of failure is linked to liquidation and is based on the UK law. Within the sample there are many SMEs that also experienced financial distress (defined as negative equity) before failure. Financial distress is therefore an interim status that may take place in some, but not necessarily all, firms prior to failure.

The definition of the UK regions follows the EU's Classification of Territorial Units for Statistics (referred to as NUTS); regional data was gathered at the NUTS-1 level.

In relation to financial performance, we gathered information on a number of financial ratios that represent the key aspects of profitability, liquidity, indebtedness, 
cash flow, working capital and firm growth. The ratios have been selected based on evidence from previous studies. As discussed in the literature review section, these ratios are: $R O I$ : the return on investment is used as an indicator of profitability and is defined as profit (loss) divided by total assets. Growth rate: defined as the year on year percentage growth in a firm's total assets. NSTA: Net Sales to total Assets is an indicator of the firm's ability to generate sales from its assets. CFTS: Cash flow to Sales ratio shows the ability of the firm to generate cash and build a cash buffer. Quick Ratio: is a measure of liquidity, defined as current assets minus liabilities divided by current liabilities. QACA: is the Quick Assets to Current assets ratio and represents a measure of a firm's working capital. TCTL: is Trade Credit to Total Liabilities and measures the usage of trade credit as a percentage of the total liabilities of the firm.

The experience, knowledge, potential connections and diversity of the firms' directors (Adams and Ferreira, 2009; Wilson et al., 2014) were measured with three ways. First, average age of directors (Avg_dir_age), which is a reflection of the experience in the board. Second, the number of directors (Total_dir_nr) which is a measure of the breadth of knowledge of the board. Third, the number of female directors (Nr_Female_Dr) provides a measure of the gender diversity of the board. The final firm-specific variable is the age of the firm (Firm_age).

The second type of data includes control variables that are not firm-specific. Instead, they relate to the business and economic environment in which the firms operate. Given that these variables are not firm-specific, they are not used to identify the alternative firm failure processes but are included in the analysis of the determinants of firm failure. First, GDP_gr is the growth in gross domestic product which is used as a proxy for the wider economic environment. The second economic environment variable is credit availability $(C R)$ in the UK. This is measured by the credit that financial institutions provide to the private sector as a percentage of the UK's GDP. This is relevant because our study includes the recent financial crisis period which was characterised by reduced credit availability. The third environment variable is the Standard Industrial Classification (SIC) classification of each firm which controls for industry effects (Gupta et. al., 2015; Perry 2001; Edmister, 1972). The industry of the firm has been identified as a determinant of firms' failure given due to the differences in the business cycles of the alternative sectors. For example, in a number of countries, the manufacturing sector has been identified as one sector with higher firm 
failure rates because of the capital commitment that it requires (Lowe et al., 1991; Sharabany, 2004). Although such observations are to some extend affected by the definition of failure used, it remains the case that some variability between sectors exists (Watson and Everett, 1999).

The fourth business environment variable measures the potential increases in the competition within each UK region by considering the number of new firms created within a given UK region in a given year as a percentage of the firm population in that area (NNF).

Descriptive statistics for the sample are reported in Table I. Poor financial performance is shown by the negative mean ROI and CFTA figures. The average number of directors is 2 . The average age of directors is 51 . The average age of firms was 18 years. On average new firms made up $2.5 \%$ of the total number of firms.

Table I: Descriptive statistics of the continuous variables for failed UK SMEs.

\begin{tabular}{lrrrr}
\multicolumn{1}{c}{ Variable } & Mean & \multicolumn{1}{c}{ St.Dev } & \multicolumn{1}{c}{ Min } & \multicolumn{1}{c}{ Max } \\
\hline roi & -1.46 & 40.65 & -127.20 & 25.32 \\
growth_rate & 21.53 & 53.87 & -1.00 & 266.15 \\
nsta & 5.92 & 79.71 & -0.01 & 251.17 \\
cfts & -1.25 & 25.24 & -784.45 & 2.99 \\
quick_ratio & 7.70 & 43.55 & 0.00 & 79.00 \\
tlta & 2.90 & 56.65 & 0.00 & 71.00 \\
qaca & 0.97 & 0.34 & 0.01 & 2.00 \\
tctl & 0.25 & 0.25 & 0.00 & 1.00 \\
firmage & 18.49 & 14.90 & 1.00 & 83.00 \\
\hline Total_dir_nr & 2.29 & 1.11 & 1.00 & 24.00 \\
Nr_Female_Dir & 0.20 & 0.84 & 0.00 & 3.00 \\
Avg_dir_age & 50.42 & 10.04 & 20.00 & 75.00 \\
\hline CR & 176.16 & 19.50 & 144.51 & 200.61 \\
GDP_gr & 1.05 & 2.28 & -4.19 & 3.00 \\
NNF & 2.53 & 2.77 & 0.70 & 8.10 \\
\hline
\end{tabular}

\section{Methodology}

The variables dealing with firm-specific characteristics were used in the initial factor and cluster analyses, the object of which is to test for the existence of different failure processes. The second part of the analysis, the regression analysis, investigates the determinants of the failure processes, includes the both firm-specific and non-firm specific variables. 
The first stage of the analysis uses a combination of factor analysis and cluster analysis on a number of firm-specific characteristics representing financial ratios, board characteristics and the age of the firm. The factor analysis, uses 7 years of data for each financial ratio. Other studies in the area generally use between 2-6 years of prior financial information to ascertain the presence of firm failure processes (for example Laitinen, 1991; Laitinen, and Lukason, 2014). Given the linear nature of the variable, firm age enters the factor analysis as it is in the last year for which firm data is available. Directors' characteristics enter the factor analysis as at the year prior to failure.

In order to ensure that the statistical properties of the sample allow the application of factor analysis, we applied the Bartlett Test of Sphericity, and the Kaiser-Meyer-Olkin (KMO) measure of sample adequacy and we confirmed that the statistical conditions necessary for factor analysis to be undertaken were present. The Bartlett test of Sphericity showed that the no autocorrelation assumption is strongly rejected (<0.000); the KMO test to measure sampling adequacy is 0.715 , which is an acceptable score to proceed with factor analysis.

Factor analysis and VARIMAX orthogonal rotation are then undertaken. Factors with Eigenvalues $\geq 1$ is used to provide the inputs for the Cluster analysis. Finally, cluster analysis is used to create clusters of firms with homogeneous within-cluster characteristics, using k-medians with Euclidean distance to avoid the influence of any outliers (Whelean et al., 2015; Lukason and Laitinen, 2016). The optimal number of clusters is determined by using the Caliński and Harabasz (1974) index. These clusters will be then used as subsamples in the panel regressions discussed below.

The second stage of the analysis, which takes place after the firm failure processes have been identified, investigates the determinants of the firms' transition to failure. It applies an unbalanced ordered panel model, which controls for the individual heterogeneity of the firms. The ordered structure of the dependent variable takes account of the interim status of financial distress, defined as negative equity. As mentioned in the introduction section, some studies consider financial distress as indicating firm failure in its own right (Jahur and Quadir, 2012; Šarlija and Jeger, 2011). In addition, other studies that consider liquidation as firm failure tend not to include financial distress as an interim stage (Altman and Sabato, 2007; Baixauli and Módica-Milo, 2010). However, we include the interim status which allows an analysis 
of the full process from a firm being healthy to becoming financially distressed and to finally liquidate. As such, the study bridges the gap between analysing financially distressed and liquidated firms in isolation.

The dependent variable takes the value of 0 for the years that firms are active and not in in financial distress. It takes the value of 1 for the years that firms are active but in financial distress and 2 for the year of failure. The ordered model captures the determinants of the firms' transition from financial health (status 0 ), to financial distress, (status 1), and then to the failure stage (status 2). The generic form of the model is:

$F S_{i t}=\sum F R_{i t}+\sum D I R_{i t}+\sum D I N D_{i t}+\sum D C_{i t}+N N F+C R_{i t}+G D P_{-} g r_{i t}$

Where FS is the firm's failure status in the form of an ordered choice variable. FR represents the financial ratios used in the model. DIR represents the directors' characteristics. DIND represents the dummy variables for the industrial classification of the firm, DC represent the dummy variables for the region. NNF represents the number of new firms in a region as a percentage of the firm population in that region (in a given year). CR represents the credit availability as a percentage of the GDP in a given year. GDP_gr represents the annual GDP growth in a given. Time is represented by $t$ and the firm by $i$.

An ordered panel regression can be estimated by either a fixed effects, or a random effects, model. The random effects specification was been selected for two reasons. First, a number of the control variables can be regarded as showing individual fixed effects (industry, region) and are therefore time invariant. This means that a fixed effects model is inappropriate. Second, the existence of fixed effects in the context of the time-varying covariates was tested by running a random effects model and keeping only the time varying variables. The group means of the variables were added to control for potential correlation between the individual effects and the regressors (Greene and Hensher, 2010). A likelihood ratio test was performed in the form of a variable addition test of the joint significance of the group means. The results of the test did not reject the null hypothesis that the coefficient of the group means are zero (10 degrees of freedom; $p=0.01$ ) and therefore a random effects model is 
appropriate. The Ordered Random Effects model is estimated using the maximum likelihood estimator.

\section{Results and Discussion}

\section{Results-Failure Processes}

The first part of the analysis employs factor and cluster analysis to examine factors that are associated with firm failure and to identify and compare failure processes. The factor analysis identified 13 factors (unrotated) that have an eigenvalue $\geq 1$ (Appendix Table A1). These factors explain $87.6 \%$ of the total variation. The factors are then rotated in order to maximise the variance of the squared loadings of the factors and increase the differentiation of the original variables in each extracted factor, by applying the VARIMAX rotation.

The above factors are then used as inputs in the K-medians cluster analysis. The Caliński and Harabasz (1974) metric maximises when there are 4 firm clusters, producing a Pseudo-F value of 58.08. The identification of different firm failure clusters offers support for hypothesis H1. Further, the identification of 4 firm failure processes is consistent with the literature which provides evidence for the existence of between 2 and 6 firm failure processes (see for example Argenti, 1976; Ooghe and DePrijcker, 2008. Laitinen et al, 2014; Laitinen and Lukason, 2015; Lukason and Laitinen, 2016). The clusters, representing the firm failure processes, have the characteristics described in Table II. As shown in the table, the four failure processes show different firm characteristics. 
Table II: Firm Failure Processes' Characteristics

\begin{tabular}{|cl|}
\hline $\begin{array}{c}\text { Firm Failure } \\
\text { Process }\end{array}$ & \multicolumn{1}{c|}{ Characteristics } \\
\hline 1 & $\begin{array}{l}\text { The first process is associated with firms that are } 22 \text { years old and, have more than } 2 \text { (2.6) directors }(0.23 \\
\text { women) in total whose average age is } 52.5 \text { years. These are firms with deteriorating growth rate and relatively } \\
\text { high usage of trade credit. } \\
\text { The second process is associated with firms that are } 19 \text { years old, have more than } 2 \text { (2.2) directors }(0.22 \\
\text { women) with an average age of } 51.5 \text { years. These firms are characterized from their inability to create cash } \\
\text { flows out of their sales despite their sales generation ability being strong. }\end{array}$ \\
The third process is associated with firms that are 19 years old, have less than 2 (1.9) directors $(0.31$ \\
female) with an average age of 49.9 years. These firms appear to have limited usage of trade credit but a \\
deteriorating ability to generate cash flows and ROI but an increasing growth in total assets. \\
The fourth process is associated with firms that are 9 years old, have more than $2(2.7)$ directors $(0.20$ \\
female) of an average age of 47 years. These firms are over indebted, have cash generating ability and also \\
deteriorating liquidity, ROI and growth.
\end{tabular}

The identification of the 4 alternative firm failure clusters (and therefore processes) confirms $\mathrm{H} 1$ that failed UK SMEs experienced different firm failure processes.

Given the identification of 4 firm failure processes, we then looked at the concentration of firms in these clusters across the UK regions. In terms of total firm failures, Table III shows that most firms appear in cluster 1 . Cluster 4 is the one with the least number of firms. In terms of the individual regions, London has the largest number of failed firms, reflecting the overall higher business population in the area. In London, most firms are concentrated on the first firm failure process. Failed firms in Yorkshire and the Humber, East Midlands, N. West, Scotland S. West and West Midlands are also more concentrated in the first firm failure process. This suggests that the first firm failure process with its characteristics of deteriorating growth rate and the relatively high usage of trade credit is symptomatic of the majority of the firms. In contrast, East Anglia, N. Ireland, N. East, and Wales are mostly concentrated in the third firm failure process which is characterised by firms with a deteriorating ability to generate cash. The least common failure process is process 4 which is characterised by over-indebted firms with deteriorating liquidity and growth. 
Table III: Distribution of UK firms in each of the clusters by region

\begin{tabular}{|c|c|c|c|c|c|c|c|c|c|c|c|c|c|}
\hline Cluster & $\begin{array}{c}\text { Yorkshire } \\
\& \\
\text { Humber }\end{array}$ & East & $\begin{array}{c}\text { East } \\
\text { Midlands }\end{array}$ & London & N.Ireland & $\begin{array}{l}\text { North } \\
\text { East }\end{array}$ & $\begin{array}{l}\text { North } \\
\text { West }\end{array}$ & Scotland & $\begin{array}{r}\text { South } \\
\text { East }\end{array}$ & $\begin{array}{l}\text { South } \\
\text { West }\end{array}$ & Wales & $\begin{array}{c}\text { West } \\
\text { Midlands }\end{array}$ & Total \\
\hline 1 & $47(45 \%)$ & $13(32 \%)$ & $15(45 \%)$ & $156(42 \%)$ & $7(35 \%)$ & $6(35 \%)$ & $61(40 \%)$ & $20(37 \%)$ & $24(32 \%)$ & $11(44 \%)$ & $5(28 \%)$ & $28(39 \%)$ & 393 \\
\hline 2 & $12(12 \%)$ & $7(17 \%)$ & $5(15 \%)$ & $71(19 \%)$ & $3(15 \%)$ & $3(18 \%)$ & $29(19 \%)$ & $11(20 \%)$ & $16(22 \%)$ & $6(24 \%)$ & $4(22 \%)$ & $12(17 \%)$ & 179 \\
\hline 3 & $33(32 \%)$ & $17(41 \%)$ & $13(39 \%)$ & $93(25 \%)$ & $8(41 \%)$ & $7(41 \%)$ & $49(32 \%)$ & $15(28 \%)$ & $24(32 \%)$ & $7(28 \%)$ & $6(33 \%)$ & $23(32 \%)$ & 295 \\
\hline 4 & $12(12 \%)$ & $4(10 \%)$ & $0(0 \%)$ & $49(13 \%)$ & $2(10 \%)$ & $1(6 \%)$ & $14(9 \%)$ & $8(15 \%)$ & $10(14 \%)$ & $1(4 \%)$ & $3(17 \%)$ & $8(11 \%)$ & 112 \\
\hline Total & 104 & 41 & 33 & 369 & 20 & 17 & 153 & 54 & 74 & 25 & 18 & 71 & 979 \\
\hline
\end{tabular}

\section{Results - Transition towards Failure}

The second step of the analysis is to investigate whether the determinants of the transition from financial health to financial distress and ultimately to failure, are the same for all four firm failure processes. As discussed in earlier sections, whilst the firm failure process characteristics are common between the firms of a failure process, not all of them are necessarily determinants of the firms' transition to failure. As a result not all of the firm-specific characteristics reported in Table II are causing firms to fail. In order to investigate that, an ordered random effects model, (see Equation 1), using standard errors ${ }^{1}$, is applied to each of the firm clusters. In addition, the model is also applied to the full sample of firms. The results of the 5 panel regressions are presented in Table IV. The LR tests show that all models are statistically significant.

The results for all firms, column 2, show that the model has identified a number of significant variables that explain the failure transition of UK SMEs. As Table IV shows, a number of financial variables were found to be significant. We also found evidence that board characteristics, firm age, firm growth and the economics and business environment were significant determinants of the process of firm failures.

\footnotetext{
${ }^{1}$ A robustness check was subsequently performed using bootstrapped errors. The results remained unchanged in terms of the significance and direction of the signs of the coefficients.
} 
Table IV: Determinants of the transition to failure in alternative UK firm failure processes

\begin{tabular}{|c|c|c|c|c|c|c|c|c|c|c|}
\hline Column Number: & \multicolumn{2}{|l|}{1} & 2 & & 3 & & 4 & & 5 & \\
\hline \multirow{2}{*}{$\begin{array}{c}\text { Independent } \\
\text { Variables }\end{array}$} & \multirow{2}{*}{\multicolumn{2}{|c|}{$\begin{array}{c}\text { All } \\
\text { Firms }\end{array}$}} & \multicolumn{8}{|c|}{ Cluster Number: } \\
\hline & & & \multicolumn{2}{|l|}{1} & \multicolumn{2}{|l|}{2} & \multicolumn{2}{|l|}{3} & \multicolumn{2}{|l|}{4} \\
\hline \multicolumn{11}{|c|}{ Coeff. } \\
\hline \multicolumn{11}{|c|}{$P>|z|$} \\
\hline roi & -0.002 & & -0.195 & $* * *$ & -0.505 & $* * *$ & 0.020 & & -0.165 & $* * *$ \\
\hline nsta & -0.001 & & 0.017 & & -0.048 & $* * *$ & -0.051 & & 0.034 & \\
\hline cfts & -0.011 & $* *$ & -0.065 & $* * *$ & -0.013 & & -0.008 & $* *$ & 0.000 & \\
\hline quick_ratio & -0.002 & & -0.012 & $*$ & -0.009 & $* *$ & -0.007 & & 0.000 & \\
\hline growth_rate & 0.004 & $* * *$ & 0.002 & & 0.284 & $* * *$ & 0.005 & $* * *$ & 0.096 & $*$ \\
\hline tl ta & 0.001 & & 0.400 & $* * *$ & 0.425 & $* * *$ & 0.017 & & 0.083 & $* *$ \\
\hline qaca & -0.641 & $* * *$ & -0.483 & $*$ & 0.330 & & -0.933 & $* * *$ & -1.217 & $* * *$ \\
\hline tctl & -1.905 & $* * *$ & -2.498 & $* * *$ & 0.158 & & -0.031 & & -2.150 & $*$ \\
\hline firm_age & -0.036 & $* * *$ & -0.038 & $* * *$ & -0.046 & $* *$ & -0.014 & & 0.017 & \\
\hline average_dir_age & -0.038 & $* * *$ & -0.007 & & -0.001 & & -0.041 & $* *$ & -0.045 & $* *$ \\
\hline female_nr & -0.060 & & -0.114 & $* *$ & 0.126 & & -0.260 & $* * *$ & 0.119 & \\
\hline number_of_directors & 0.013 & & 0.002 & & -0.007 & & 0.046 & $* * *$ & -0.045 & \\
\hline GDP_gr & -0.043 & $* *$ & -0.018 & & 0.136 & & -0.075 & $*$ & -0.143 & $*$ \\
\hline CR & -0.009 & $* * *$ & -0.011 & $* *$ & 0.025 & $* *$ & -0.009 & $* *$ & -0.024 & $* *$ \\
\hline NNF & 0.089 & $* *$ & 0.074 & $*$ & 0.407 & $* * *$ & 0.180 & $* * *$ & 0.415 & $* * *$ \\
\hline Control_Ind (Agriculture) & -4.016 & $* *$ & -0.433 & & -1.553 & & -0.870 & $*$ & -1.044 & \\
\hline Control_Ind (Mining) & -2.912 & & 0.293 & & -24.937 & & 1.506 & & 2.233 & $*$ \\
\hline Control_Ind (Construction) & -3.914 & $* *$ & -0.446 & & -2.899 & & -0.226 & & 0.153 & \\
\hline Control_Ind (Manufacturing) & -3.364 & $*$ & -0.064 & & -0.295 & & -0.535 & & -1.338 & \\
\hline Control_Ind (Trasp. \& Comm.) & -3.408 & $*$ & -0.392 & & 0.235 & & -0.079 & & -2.118 & * \\
\hline Control_Ind (Wholesale) & -3.930 & $*$ & -0.568 & $*$ & -2.419 & & 0.063 & & -1.391 & \\
\hline Control_Ind (Retail) & -4.011 & $*$ & -0.439 & & -1.162 & & -0.831 & & 0.234 & \\
\hline Control_Ind (R. Estate) & -3.303 & & -0.110 & & -0.416 & & -0.313 & & 0.319 & \\
\hline region_York & 0.257 & & 0.342 & & -1.993 & $*$ & 0.824 & * & 1.328 & \\
\hline region_east & 0.233 & & 0.436 & & 1.204 & & 0.099 & & -1.843 & \\
\hline region_east_midlands & 0.576 & & 0.617 & & -2.308 & & 0.858 & & 7.718 & $* * *$ \\
\hline region_n_ireland & 0.949 & $*$ & 1.480 & $* *$ & -3.505 & & 1.855 & $* * *$ & 1.074 & \\
\hline region_north_east & 0.564 & & -0.006 & & -3.756 & $*$ & 4.048 & $* * *$ & 1.042 & \\
\hline region_north_west & 0.153 & & 0.420 & & -0.931 & & 0.156 & & 1.300 & \\
\hline region_scotland & 1.165 & $* * *$ & 1.240 & $* * *$ & -0.518 & $*$ & 0.898 & $*$ & 2.215 & $* *$ \\
\hline region_south_east & 0.148 & & 0.295 & & -2.766 & $* *$ & 1.130 & & 1.043 & \\
\hline region_south_west & -0.432 & & -0.218 & & -1.525 & & -0.303 & & -2.659 & \\
\hline region_wales & -0.467 & & -0.217 & & -26.055 & & -1.224 & & 0.599 & \\
\hline region_west_midlands & 0.365 & & 0.780 & $* *$ & -4.239 & $* *$ & 1.314 & $* * *$ & 3.171 & $* *$ \\
\hline Icut1 & -5.265 & & -0.465 & & 0.601 & & 0.013 & & -2.025 & \\
\hline \cut2 & -2.913 & & 1.678 & & 6.465 & & 1.683 & & 2.421 & \\
\hline Sigma_2u & 3.416 & & 1.787 & & 6.189 & & 2.422 & & 0.840 & \\
\hline std. ErrorSigma_2u & 0.319 & & 0.298 & & 1.708 & & 0.435 & & 0.360 & \\
\hline LR test vs. ologit model & 958.440 & $* * *$ & 155.980 & $* * *$ & 123.700 & $* * *$ & 205.450 & $* * *$ & 0.360 & $* * *$ \\
\hline
\end{tabular}


The results shown in the next four columns relate to the four identified firm failure processes and show the importance of not treating firm failure as a homogeneous concept. The key general finding is that, although there is some overlap, different characteristics (or combinations of characteristics) determine the four alternative firm failure processes and that a comparison with the all firms' results shows a substantial degree of difference. For example, in relation to the financial variables, ROI is significant and negative for three of the processes but not the whole sample. Net Sales to Total Assets (nsta) is negative and significant in the second firm failure process only. Cash Flow to Sales (cfts) is significant and negative in the first and third firm failure processes. Quick ratio is significant and negative in the first and second firm failure process. Total Liabilities to Total Assets (tlta) is positive and significant in all but the third firm failure process but it is not significant in the all firms' results (column 1). Quick Assets to Current Assets (qaca) is negative and significant in all but the second firm failure process and Trade Credit to Total Liabilities (tctl) is significant and negative in all but the second and third firm failure processes. Firm growth rate is significant in different firm failure processes. It was a determinant of firms' transition towards failure for all but the first firm failure process and its positive sign indicates that high growth is associated with firms' transition towards failure. In general, across the different failure processes, failed firms exhibited poor financial performance and the financial ratios that were identified as significant were different in the alternative firm failure processes.

Therefore, the regression findings show that a number of financial variables were found to be significant determinants of firms' transition to failure. In addition, the statistically significant financial ratios are different between the alternative firm failure processes. As such there is support for $\mathrm{H} 2$ : The financial symptoms of failure differ between UK SMEs' failure processes and are determinants of firms' transition to failure.

The results for board characteristics further show the importance of analysing the individual failure processes rather than just looking at failed firms as a whole. Such findings are in line with wider firm failure studies (Argenti, 1676; Ropega, 2011). In addition, these results also demonstrate that there are variations in the determinants of firms' failures in the alternative firm failure processes. For example, although director age is significant for all firms, it is only significant and negative for failure 
processes 3 and 4 . That implies that the younger age (and therefore less experience) in directors is associated with firms' transition to failure in these firm failure processes. The results also show that neither the number of directors nor the number of female directors is significant for the whole sample but the former is positive and significant for the third process whilst the latter is significant for the first (column 2) and the third (column 4) process with a negative coefficient. This implies that the decreased gender diversity (proxied by the number of female directors) is a determinant of firms' transition to failure in these firm failure processes. These findings provide supportive evidence for H3: The director characteristics of UK SMEs differ in alternative firm failure processes and are determinants of firms' transition to failure.

The results in Table IV also show that firm age is a negative and significant determinant of the transition towards failure in the first and second firm failure processes. Whilst qualitative firm failure studies had identified the age of the firm as a characteristic that could differ between firm failure processes (Argenti, 1976; Richardson et al., 1994), these results extend such findings in the context of quantitative firm failure process studies. This implies that whilst, for example, young firms do experience a different firm failure process (see the fourth firm failure process, Table IV), age is not a significant determinant of the transition towards failure for young firms. As a result, there is partial support for H4: Firm age differs in the alternative firm failure processes of the UK SMEs and is a determinant of firms' transition to failure.

In terms of the macroeconomic and business environment, the results show that all processes are affected by credit availability and the rate of firm entry. Economic (GDP) growth is significant in all cases except for processes one and two and negatively associated with firms' transition to failure. The results suggest that macroeconomic conditions affect most firms but that they have less of an impact on some failure processes. In addition, the increased business competition in a region, proxied by the percentage of new firms (NNF) in a region is significant in all firm failure processes. There is limited evidence that sectoral differences affect the different failure processes. However, there are regional differences with a number of regions showing process differences, including Yorkshire, East Midlands, West Midlands and the North East. As a result, there is support for H5: Economic and business 
environment conditions are significant determinants of firms' transition to failure. However, one should note that there are still differences between the alternative firm failure processes, for example, GDP growth is not a significant determinant of firms' determinant of failure in the first and second firm failure process.

\section{Conclusion}

This paper undertook a quantitative analysis of the firm failure process of UK failed SMEs and found that different firm failure processes exist among failed UK SMEs. It is the first quantitative study that investigates the impact of non-financial, firm-specific information, for example, director characteristics, on UK SMEs' failure process. As such, this study builds upon the evidence from the associated qualitative firm failure process literature (see for example Argenti, 1976; Ooghe and De Prijcker, 2008) and extends the existing quantitative firm failure process literature (for example Laitinen, 1991; Laitinen and Lukason, 2014; Lukason et al., 2014). It therefore helps to bridge the gap between the two literatures. In addition, the study examined the determinants of the different failure processes, something that previous quantitative firm failure studies did not explore. The study extends the existing firm failure process literature by analysing the impact that firm-specific and business environment-specific determinants from the wider firm failure literature have on firms' failure, within the alternative UK firms' failure processes.

The results show that, consistent with $\mathrm{H} 1$, there are four alternative firm failure processes among UK SMEs. This is consistent with evidence from other qualitative and quantitative firm failure process studies (Laitinen et al, 2014; Laitinen and Lukason, 2014; Lukason and Laitinen, 2016). The differences in the role of financial performance measures supports $\mathrm{H} 2$. Whist this finding supports the existing quantitative firm failure process literature (see for example, Laitinen, 1991; Lukason and Vissak, 2017) in showing that the financial characteristics differ in the alternative firm failure processes, it also extends the existing literature by showing that the financial ratios also differ as determinants of the firms' transition to failure within the alternative firm failure processes. The results for board characteristics show that their importance varies across failure processes, confirming H3. In addition, firm age was also found to significantly affect a number of failure processes, offering support for 
H4. These findings empirically confirm evidence from the qualitative firm failure process literature (Argenti, 1976; Richardson et al., 1994; Ooghe and De Prijcker, 2008) in a quantitative context. We also find evidence that supports $\mathrm{H} 5$ that the business and economics environment affect firm failure across the different failure processes.

Overall, the results of the analysis of the determinants of the transition towards failure explain the importance of not treating firm failure as a homogeneous concept. Although there is some overlap, different factors were found to affect different failure processes.

A number of policy implications result from these findings that can be useful to policy makers, lenders and financial restructuring professionals. Policies and decisions designed to support SMEs and to avoid failure should be targeted according to the characteristics of the firm and the process towards failure with which it is associated. It is therefore unlikely that generic approaches and assessments of the likelihood of bankruptcy are equally applicable to all of the different firm failure processes.

The identification of four firm failure processes and the main firm characteristics that they represent, suggest that policies designed to assist SMEs avoid failure should take into account the characteristics of the firms within this firm failure process context. For example, old firms with deteriorating growth and relatively large boards would require different supporting mechanisms from young over-indebted firms to avoid failure given that the determinants of the' transition to failure of the latter are much more impacted by adverse changes in the economic environment, compared to the former.

Likewise, lenders and financial restructuring professionals should be aware of the different firm failure process when assessing a firm's propensity to fail. Different firm failure processes result in different determinants of firms' transition to failure and as such, care should be taken to avoid a "one size fits all" (Denmary et al., 2016) solutions in firms' financing or restructuring to avoid failure.

The results also have implications for decision-making in SMEs, particularly in relation to social capital, for example, an awareness of the benefits of board gender 
balance in relation to decision-making. Therefore, educational programs designed to explain the benefits of diversity amongst directors and policies to promote it, will widen the awareness of different attitudes to risk-taking and also increase a board's human capital.

This study has a number of limitations. First, it analyses only UK SMEs. Therefore an analysis of other countries might provide additional insights into the failure of SMEs. Second, a larger sample with more firms could provide further insight in the alternative firm failure processes. Third, an understanding of the importance of further managerial characteristics may also provide insights into the failure process. Studies could further investigate the characteristics of the firms' directors and entrepreneurs in an attempt to evaluate how their attitude and managerial behaviour towards the firm changes over time. For example, an understanding of a manager's leadership style may provide additional insights into how it affects SME failure. In addition, further research can be done to analyse the impact of previous firm failures or prior board experience that some directors and entrepreneurs may have had and evaluate whether such characteristics play a part in the firm failure processes of UK firms. 


\section{References}

Adams, R.B., Ferreira, D., (2009), "Women in the boardroom and their impact on governance and performance", Journal of Financial Economics, Vol. 94 No. 2, pp. 291-309.

Adams, R.B., Funk, P., (2012), "Beyond the glass ceiling: Does gender matter?", Management science, Vol. 58 No. 2, pp.219-235.

Argenti, J., (1976), "Corporate planning and Corporate Collapse”, Long Range Planning, Vol. 9 No. 6, pp. 12-17.

Altman, E. I., (1968), "Financial Ratios, Discriminant Analysis and the Prediction of Corporate Bankruptcy", Journal of Finance, Vol. 23 No. 4, 589-609.

Altman, E.I., Sabato, G., (2007), "Modelling Credit Risk for SMEs: Evidence from the U.S. Market", Abacus, Vol.43 No.3,pp. 332-357.

Altman, E., I., Sabato, G., Wilson, N. (2010), "The value of non-financial information in small and medium-sized enterprise risk management", The Journal of Credit Risk, Vol. 6 No. 2, pp.95-127.

Baixauli, J. S., Módica-Milo, A., (2010), "The bias of unhealthy SMEs in bankruptcy prediction models", Journal of Small Business and Enterprise Development, Vol. 17 No.1, pp.60-77.

Beaver, W.H., (1966), "Financial Ratios As Predictors of Failure", Journal of Accounting Research, Vol. 4, pp. 71-111

Bennett, R., Robson, P., (2004), 'Support Services for SMEs: Does the Franchisee' Make a Difference to the Business Link Offer?", Environment and Planning C: Politics and Space, Vol.22 No.6, pp. 859-880

Berger, A. N., Udell, G. F., (2002), "Small Business Credit Availability and Relationship Lending: The Importance of Bank Organisational Structure", The Economic Journal, Vol. 112, pp. F32-F5

Bunn, P., Redwood, V., (2003), "Company accounts based modelling of business failures and the implications for financial stability", Bank of England, working Paper no. 210, London, UK. 
Burke, R. J. (2000), "Women on Corporate Boards of Directors: Understanding the Context." [In] "Women on Corporate Boards of Directors: International Challenges and Opportunities", eds R. J. Burke and M. C. Mattis, 179-196. Dordrecht: Kluwer Academic Publishers.

Caliński, T., Harabasz, J., (1974), "A dendrite method for cluster analysis", Communications in Statistics, Vol.3 No.1, pp.1-27.

Carbo-Valverde, S., Rodriguez-Fernandez, F., Udell, G.F., (2006). "Trade Credit, the Financial Crisis, and SME Access to Finance", Journal of Money, Credit and Banking, Vol. 48 No.1, pp.113-143.

D'Aveni, R.A., (1989), "The Aftermath Of Organizational Decline: A Longitudinal Study Of The Strategic And Managerial Characteristics Of Declining Firms", Academy of Management Journal, Vol. 32 No. 3, pp.577-605.

Davidsson, P., Klofsten, M., (2003), "The Business Platform: Developing an instrument to gauge and assist the development of young firms", Journal of Small Business Management, Vol. 41 No.1, pp. 1-26.

Daily, C.M., Dalton, D.R., Cannella, A.A., (2003), "Corporate Governance: Decades of Dialogue and Data", Academy of Management Review, Vol.28 No.3, pp.371-382.

Deakin, E.B., (1972), "A Discriminant Analysis of Predictors of Business Failure", Journal of Accounting Research, Vol. 10 No. 14, pp. 167-179.

Demary, M., Hornik, J., Watfe, G., (2016). "SME financing in the EU: Moving beyond one-size-fits-all” (No. 11/2016), IW-Report.

Edmister, R.O., (1972), "An Empirical Test of Financial Ratio Analysis for Small Business Failure Prediction”, Journal of Financial and Quantitative Analysis, Vol.7 No.2, pp. 1477-1493.

Everett, J., Watson, J., (1998), "Small Business Failure and External Risk Factors", Small Business Economics, Vol.11 No.4, pp.371-390.

Falck, O., (2007), "Survival chances of new businesses: do regional conditions matter?" Applied Economics, Vol.39, pp.2039-2048.

Fabrigar, L.R., Wegener, D.T., MacCallum, R.C., Strahan,E.J., (1999), "Evaluating the Use of Exploratory Factor Analysis in Psychological Research", Psychological Methods, Vol.4 No.3, pp.272-299.

Gaiotti, E., (2011), "Credit availability and investment in Italy: lessons from the Great recession", Bank of Italy, No. 793. 
Gilbert, R.A., Meyer, A.P., Vaughan, M.D. (1999), "The Role of Supervisory Screens and Econometric Models in Off-Site Surveillance", Federal Reserve Bank of St. Louis Review, Vol. 81 No.6, pp. 31-56.

Gray, S., Nowland, J., (2013), "Is prior director experience valuable?", Accounting \& Finance, Vol. 53 No.3, pp.643-666.

Greene, W.H. Hensher, D.A. (2010), "Modelling Ordered Choices - A primer", Cambridge University Press, Cambridge.

Gupta, J., Gregoriou, A., Healy, J., (2015), "Forecasting bankruptcy for SMEs using hazard function: To what extent does size matter?", Review of Quantitative Finance and Accounting, Vol. 45 No. 4, pp 845-869.

Hair, J.F., Black, W.C., Babin, B.J., Anderson, R.E., Tatham, R.L., (2006), "Multivariate Data Analysis", Pearson Education International, New Jersey.

Hambrick, D.C., D'Aveni, R.A., (1988), "Large Corporate Failures as Downward Spirals”, Administrative Science Quarterly, Vol. 33 No. 1, pp. 1-23.

Hambrick, D.C., Mason, P.A., (1984). "Upper echelons: The organization as a reflection of its top managers", Academy of management review, Vol. 9 No.2, pp.193-206.

He C., Yang, R., (2016), "Determinants of Firm Failure: Empirical Evidence from China", Growth and Change, Vol.47 No.1, pp.72-92.

Herrmann, P., Datta, D.K., (2005), "Relationships between top management team characteristics and international diversification: An empirical investigation", British Journal of Management, Vol.16 No.1, pp.69-78.

Horváth, R.,Spirollari, P., (2012), "Do the board of directors' characteristics influence firm's performance? The US evidence", Prague economic papers, Vol.4, pp.470-486. Isidro, H., Sobral, M., (2015), "The effects of women on corporate boards on firm value, financial performance, and ethical and social compliance", Journal of Business Ethics, Vol. 132 No.1, pp.1-19.

Jahur, M.S., Quadir, S.M.N., (2012), "Financial Distress in Small and Medium Enterprises (SMEs) of Bangladesh: Determinants and Remedial Measures", Economia Seria Management, Vol.15 No.1, pp. 46-61.

Jenkins, A. and McKelvie, A., (2016), "What is entrepreneurial failure? Implications for future research", International Small Business Journal, Vol. 34 No.2, pp.176-188. 
Jumpponen,J., Ikävalko, M., Pihkala, T., (2008), "Management and change in turbulent times: How do Russian small business managers perceive the development of their business environment?", Journal of Business Economics and Management, Vol.9 No.2, pp. 115-122.

Laitinen, E.K., (1991), "Financial Ratios and Different Failure Processes", Journal of Business Finance \& Accounting, Vol. 18 No. 5, pp.649-673.

Laitinen, E. K., Lukason, O., (2014), "Do firm failure processes differ across countries: evidence from Finland and Estonia", Journal of Business Economics and Management, Vol. 15 No.5, pp. 810-832.

Laitinen, E., K., Lukason, O., Suvas, A. (2014), "Are firm failure processes different? Evidence from seven countries", Investment Management and Financial Innovations, Vol. 11 No. 4, pp.212-222.

Lane, S.J., Schary, M., (1991), "Understanding the Business Failure Rate", Contemporary Economic Policy, Vol. 9 No 4, pp.93-105.

Liu, J., (2009), "Business Failures and Macroeconomic Factors in the UK", Bulletin of Economic Research, Vol.61 No,1, pp.47-72.

Love, J.H., (1996), "Entry and exit: a county-level analysis", Applied Economics, Vol. 28 No.4, pp.441-451.

Lowe, J., McKenna, J., Tibbits. G. (1991), "Small Firm Growth and Failure: Public Policy Issues and Practical Problems", Economic Papers, Vol. 10 No. 2, pp 69-81.

Lukason, O., (2016), Characteristics of firm failure processes in an international context (Doctoral dissertation, Tartu University).

Lukason, O., Laitinen, E.K., (2016), "Failure processes of old manufacturing firms in different European countries", Investment Management and Financial Innovations, Vol. 13 No. 2, pp.310-321.

Lukason, O., Laitinen, E.K., Arto, S., (2016), "Failure process of young manufacturing micro firms in Europe", Management Decision, Vol. 54 No.8, pp.1966-1985.

Lukason, O. and Laitinen, E.K., (2016), "Failure processes of old manufacturing firms in different European countries", Investment Management and Financial Innovations, Vol.13 No.2, pp.310-321.

Lukason, O., Vissak, T., (2017), "Failure processes of exporting firms: evidence from France", Review of International Business and Strategy, Vol. 27 No.3, pp.322-334. 
Keeble, D., Walker, S., (1994), "New Firms, Small Firms and Dead Firms: Spatial Patterns and Determinants in the United Kingdom", Regional Studies, Vol. 28 No.4, pp. 411-427.

Khelil, N., (2016), "The many faces of entrepreneurial failure: Insights from an empirical taxonomy", Journal of Business Venturing, Vol. 31 No.1, pp.72-94.

Ma, Y., Lin, S., (2010), 'Credit crunch' and Small- and Medium-sized Enterprises: Aspects affecting survival", Journal of Financial Services Marketing, Vol. 14 No, 4, pp 290-300.

Moscovici, S, Faucheux, C., (1972), "Social influence, conformity bias, and the study of active minorities", Advances in experimental social psychology, Vol. 6, pp. 149-202.

Mueller, B.A., Shepherd, D.A., (2016)," Making the most of failure experiences: Exploring the relationship between business failure and the identification of business opportunities", Entrepreneurship Theory and Practice, Vol. 40 No.3, pp.457-487.

Nafziger, E.W., Terrell, D., (1996), "Entrepreneurial Human Capital and the Long-Run Survival of Firms in India", World Development, Vol. 24 No. 4, pp. 689-696.

Ooghe, H., De Prijcker, S., (2008), "Failure processes and causes of company bankruptcy: a typology", Management Decision, Vol. 46 No. 2, pp.223-242.

Parker, S., Peters, G. F., Turetsky, H., F., (2002), "Corporate governance and corporate failure: a survival analysis", Corporate Governance: The international journal of business in society, Vol. 2 No.2, pp.4-12.

Pearce, J.A., Michael, S.C., (2006), "Strategies to prevent economic recessions from causing business failure", Business Horizons, Vol.49 No.3, pp.201-209.

Perry, S.C., (2001), "The Relationship between Written Business Plans and the Failure of Small Businesses in the U.S.", Small Business Management, Vol 39 No.3, pp.201208.

Pindado, J., Rodrigues, L.F., (2004), "Parsimonious Models of Financial Insolvency in Small Companies", Small Business Economics, Vol. 22 No.1, pp.51-66.

Politis, D., Gabrielsson, J., (2009), "Entrepreneurs' attitudes towards failure: An experiential learning approach", International Journal of Entrepreneurial Behavior \& Research, Vol.15 No. 4, pp.364-383. 
Platt, H.D., (1989), "The Determinants of interindustry Failure", Journal of Economics and Business, Vol. 41 No. 2, pp.107-126.

Platt, H.D., Platt, M.B, (2002), "Predicting Corporate Financial Distress: Reflections on Choice-Based Sample Bias", Journal of Economics and Finance, Vol. 26 No.2, pp.184-198.

Platt, H., Platt, M., (2012) "Corporate board attributes and bankruptcy", Journal of Business Research, Vol. 65 No.8, pp.1139-1143.

Richardson, B., Nwankwo, S., Richardson, S., (1994), "Understanding the Causes of Business Failure Crises: Generic Failure Types: Boiled Frogs, Drowned Frogs, Bullfrogs and Tadpoles", Management Decision, Vol. 32 No.4, pp.9-22.

Šarlija, N., Jeger, M., (2011), "Comparing Financial Distress Prediction Models Before and During Recession", Croatian Operational Research Review, Vol. 2, pp.133-142.

Sharabany, R., (2004), "Business Failure and Macroeconomic Risk Factors", Bank of Israel, Discussion paper, No. 2004.06 , Israel.

Shehata, N., Salhin, A., El-Helaly, M., (2017), "Board diversity and firm performance: evidence from the UK SMEs", Applied Economics, Vol. 49 No.48, pp.4817-4832.

Thorsell, A., Isaksson, A., (2014), "Director experience and the performance of IPOs: Evidence from Sweden", Australasian Accounting Business \& Finance Journal, Vol. 8 No,1, pp.3-24.

Tsoukas, S., (2011), "Firm survival and financial development: Evidence from a panel of emerging Asian economies", Journal of Banking and Finance, Vol.35 No.7, pp. 17361752.

Vendramin, L., Campello, R.J.G.B., Hruschka, E., R., (2010), "Relative clustering validity criteria: A comparative overview", Statistical Analysis and Data Mining, Vol. 3 No.4, pp. 209-235.

Watson, J., Everett, J., (1999), "Small Business Failure Rates: Choice of Definition and Industry Effects", International Small Business Journal, Vol. 17 No. 2, pp.31-47.

Wagner, J., (2004), "Are Young and Small Firms Hothouses for Nascent Entrepreneurs? Evidence from German Micro Data", IZA Discussion paper series, No. 989, Germany. Westphal, J.D., Milton, L.P., (2000). "How experience and network ties affect the influence of demographic minorities on corporate boards", Administrative Science Quarterly, Vol.45 No. 2, pp.366-398. 
Whelan, C., Harrell, G., Wang, J., (2015), “Understanding the k-medians problem", Proceedings of the International Conference on Scientific Computing (CSC), Athens, Greece.

Wilson, N., Altanlar, A., (2009), "Director Characteristics, gender balance and insolvency risk: an empirical study", Gender Balance and Insolvency Risk: An Empirical Study (September 22, 2009).

Wilson, N., Wright, M., Altanlar, A., (2014), "The survival of newly-incorporated companies and founding director characteristics", International Small Business Journal, Vol. 32 No.7, pp. 733-758. 


\section{Appendix}

Table A.I: Eigenvalues of VARIMAX- rotated factors (with Eigenvalues >1) for UK firms; financial ratios and firm age as variables.

\begin{tabular}{lcccc}
\hline Factor & Variance & Difference & Proportion & Cumulative \\
\hline Factor1 & 5.436 & 0.005 & 0.138 & 0.138 \\
Factor2 & 5.431 & 0.299 & 0.138 & 0.275 \\
Factor3 & 5.132 & 2.053 & 0.130 & 0.405 \\
Factor4 & 3.080 & 0.417 & 0.078 & 0.483 \\
Factor5 & 2.662 & 0.270 & 0.067 & 0.551 \\
Factor6 & 2.392 & 0.428 & 0.061 & 0.611 \\
Factor7 & 1.964 & 0.126 & 0.050 & 0.661 \\
Factor8 & 1.838 & 0.161 & 0.047 & 0.708 \\
Factor9 & 1.677 & 0.114 & 0.043 & 0.750 \\
Factor10 & 1.563 & 0.058 & 0.040 & 0.790 \\
Factor11 & 1.504 & 0.310 & 0.038 & 0.828 \\
Factor12 & 1.194 &. & 0.030 & 0.858 \\
\hline \multicolumn{5}{c}{ LR test: independent vs. saturated: chi2 2278$)=3.5 \mathrm{e}+04$ Prob $>$ chi2 $=0.0000$} \\
\hline \multicolumn{5}{c}{}
\end{tabular}


Table A.II: Factor Loadings with directors' characteristics (post VARIMAX rotation) in UK firms.

\begin{tabular}{|c|c|c|c|c|c|c|c|c|c|c|c|c|}
\hline Variable & Factor1 & Factor2 & Factor3 & Factor4 & Factor5 & Factor6 & Factor7 & Factor8 & Factor9 & Factor10 & Factor11 & Factor12 \\
\hline roi & 0.0415 & -0.0746 & 0.0282 & 0.0355 & -0.1001 & 0.0141 & 0.0202 & 0.0639 & 0.0311 & 0.2652 & 0.0722 & 0.0224 \\
\hline roiL1 & -0.0101 & 0.0152 & 0.0112 & -0.5184 & -0.0081 & 0.0175 & 0.0511 & 0.0627 & 0.0161 & 0.1008 & 0.0917 & 0.0514 \\
\hline roiL2 & 0.0508 & 0.0713 & 0.0243 & 0.0393 & -0.0732 & 0.0368 & 0.0239 & 0.1834 & 0.0497 & 0.6619 & 0.2557 & 0.0067 \\
\hline roiL3 & 0.0777 & -0.0344 & -0.0171 & -0.0093 & -0.0667 & 0.0244 & -0.0049 & 0.0788 & 0.0221 & 0.1016 & 0.775 & 0.0086 \\
\hline roiL4 & 0.0941 & 0.0547 & 0.0101 & -0.044 & -0.1544 & 0.0766 & 0.0028 & 0.2698 & 0.1052 & 0.2146 & 0.3206 & 0.0151 \\
\hline roiL5 & 0.0348 & 0.081 & -0.035 & -0.0238 & -0.3154 & 0.7608 & -0.0284 & 0.2419 & -0.0963 & 0.1527 & 0.0345 & 0.0182 \\
\hline roiL6 & 0.0508 & 0.1272 & -0.0252 & -0.0168 & -0.2271 & 0.1459 & -0.0244 & 0.4852 & 0.1397 & 0.2028 & 0.076 & 0.0427 \\
\hline roiL7 & -0.0044 & 0.0298 & -0.0078 & -0.0098 & 0.0389 & -0.075 & 0.0024 & 0.0479 & 0.931 & 0.0272 & 0.0133 & 0.0068 \\
\hline growth_rate & 0.0023 & -0.0122 & -0.0056 & -0.0048 & -0.0632 & -0.002 & 0.0052 & 0.0052 & 0.016 & 0.0422 & 0.0256 & -0.0226 \\
\hline growth_rateL1 & -0.0483 & -0.003 & 0.0027 & -0.0076 & -0.0362 & 0.0004 & 0.0005 & 0.0142 & 0.0002 & -0.0035 & 0.0173 & 0.0097 \\
\hline growth_rateL2 & -0.0082 & 0.0034 & 0.0224 & 0.0381 & -0.0462 & -0.0008 & 0.0187 & 0.0326 & -0.0027 & 0.3849 & -0.1422 & 0.0008 \\
\hline growth_rateL3 & -0.0085 & 0.0419 & 0.0048 & -0.005 & -0.071 & 0.0197 & -0.0041 & 0.0949 & 0.034 & 0.0766 & -0.6782 & 0.0308 \\
\hline growth_rateL4 & -0.0735 & 0.048 & -0.0182 & -0.0062 & 0.1545 & -0.0834 & -0.023 & 0.1383 & 0.2192 & -0.0522 & -0.0572 & 0.2362 \\
\hline growth_rateL5 & -0.05 & -0.0398 & 0.0138 & 0.2099 & 0.1731 & -0.1494 & -0.0546 & 0.0645 & 0.2322 & -0.0189 & 0.0389 & 0.2462 \\
\hline growth_rateL6 & 0.0176 & 0.0133 & 0.0167 & 0.0477 & 0.1139 & -0.0093 & -0.0512 & -0.0353 & -0.0444 & 0.0469 & -0.021 & 0.3673 \\
\hline growth_rateL7 & -0.1446 & -0.0042 & -0.041 & 0.0291 & 0.1567 & 0.1285 & -0.022 & -0.5791 & 0.1045 & 0.0369 & -0.0068 & 0.0349 \\
\hline nsta & 0.0011 & -0.0173 & 0.2125 & 0.0506 & -0.0201 & -0.0041 & -0.0026 & 0.0157 & -0.0044 & 0.0042 & 0.013 & -0.0356 \\
\hline nsta_L1 & 0.0316 & -0.0083 & 0.9241 & -0.016 & -0.0321 & 0.0044 & 0.0026 & -0.0106 & -0.0136 & -0.0214 & 0.0113 & -0.0698 \\
\hline nsta_L2 & 0.0358 & 0.0162 & 0.905 & 0.0098 & -0.0442 & -0.0096 & 0.0029 & -0.0347 & -0.0086 & 0.1958 & -0.0088 & -0.106 \\
\hline nsta_L3 & 0.0507 & 0.0048 & 0.7787 & -0.0178 & -0.0628 & -0.0092 & -0.0121 & -0.0321 & 0.0172 & 0.0298 & 0.0082 & -0.134 \\
\hline nsta_L4 & 0.0832 & -0.0021 & 0.8633 & -0.0247 & -0.068 & -0.0194 & 0.0005 & -0.0253 & 0.0131 & 0.0249 & -0.0094 & -0.0796 \\
\hline nsta_L $\mathrm{L} 5$ & 0.0831 & -0.005 & 0.8322 & -0.0228 & 0.1402 & 0.0106 & 0.0089 & 0.0463 & -0.0001 & -0.0675 & 0.0083 & 0.1154 \\
\hline nsta_L6 & 0.1173 & 0.0233 & 0.8379 & 0.0266 & 0.1206 & 0.0088 & 0.0008 & 0.0508 & -0.007 & -0.0955 & -0.0117 & 0.174 \\
\hline nsta_L7 & 0.1595 & 0.0323 & 0.7646 & 0.0161 & 0.0786 & -0.0243 & 0.0079 & 0.0841 & -0.0048 & -0.0944 & -0.0174 & 0.2135 \\
\hline $\mathrm{cfts}^{-}$ & 0.0445 & -0.0033 & 0.0285 & 0.0006 & 0.0104 & 0.003 & -0.0003 & -0.0235 & -0.0024 & 0.0157 & -0.0049 & 0.0041 \\
\hline cfts_L1 & 0.0156 & -0.009 & 0.014 & -0.9701 & 0.1019 & 0.0067 & -0.0009 & -0.0115 & -0.0181 & 0.0949 & -0.0265 & -0.02 \\
\hline cfts_L2 & -0.0019 & -0.0634 & 0.0276 & -0.0125 & 0.0234 & 0.0347 & 0.036 & 0.1688 & 0.0273 & -0.0465 & 0.0533 & -0.1074 \\
\hline cfts_L3 & 0.1176 & -0.0398 & 0.0394 & -0.0322 & -0.0899 & 0.0467 & 0.0727 & 0.3035 & 0.0218 & -0.1309 & 0.2033 & -0.1158 \\
\hline cfts_L4 & 0.0369 & -0.0739 & 0.0263 & 0.0034 & 0.0126 & 0.0235 & 0.0234 & 0.187 & -0.0049 & -0.0504 & -0.0095 & -0.0144 \\
\hline cfts_L5 & 0.0029 & 0.0137 & -0.0127 & -0.0072 & -0.0831 & 0.8783 & 0.0017 & 0.0037 & 0.0696 & -0.0214 & -0.0219 & -0.0198 \\
\hline cfts_L6 & 0.0602 & 0.0253 & 0.0202 & 0.0028 & -0.0537 & 0.075 & 0.031 & 0.3762 & -0.0069 & -0.0303 & -0.0069 & -0.0956 \\
\hline cfts_L7 7 & 0.1239 & 0.0301 & 0.0332 & -0.006 & -0.0382 & 0.0399 & 0.0278 & 0.7482 & -0.0845 & 0.0214 & 0.0001 & 0.043 \\
\hline quick_ratio & -0.1075 & 0.013 & -0.0239 & -0.0682 & -0.1403 & 0.0397 & 0.2672 & 0.0476 & 0.0119 & 0.033 & 0.0629 & 0.2585 \\
\hline quick_ratioL1 & -0.041 & 0.0141 & 0.0058 & -0.0011 & -0.0115 & -0.0068 & 0.9058 & 0.0036 & -0.0027 & -0.0017 & -0.0069 & -0.0111 \\
\hline quick_ratioL2 & -0.0557 & 0.0109 & 0.0056 & -0.0121 & -0.0277 & -0.0089 & 0.9194 & 0.0191 & -0.0007 & -0.0082 & 0.0051 & 0.0074 \\
\hline quick_ratioL3 & -0.0732 & 0.0164 & -0.0091 & -0.0194 & -0.0543 & 0.0042 & 0.3313 & -0.0273 & -0.0125 & 0.0447 & 0.0319 & 0.1686 \\
\hline quick_ratioL4 & -0.0923 & -0.0008 & 0.0004 & -0.0203 & -0.1015 & 0.0213 & 0.1438 & -0.0211 & -0.0179 & -0.0312 & 0.0639 & 0.3097 \\
\hline quick_ratioL5 & -0.0801 & 0.0041 & 0.0112 & -0.0015 & -0.0506 & 0.0169 & 0.0788 & -0.0179 & -0.0308 & -0.0024 & 0.0413 & 0.2857 \\
\hline quick_ratioL6 & -0.0485 & 0.1346 & 0.0065 & -0.0031 & -0.0389 & -0.0037 & 0.0076 & -0.0123 & -0.0129 & -0.0121 & 0.0299 & 0.0742 \\
\hline quick_ratioL7 & -0.0268 & 0.0045 & -0.0005 & 0.0016 & -0.0602 & -0.0034 & 0.1318 & -0.0032 & -0.0033 & 0.0024 & 0.0082 & 0.261 \\
\hline tlta & -0.0315 & -0.0021 & -0.0131 & 0.9746 & 0.0886 & 0.0176 & 0.0001 & 0.0106 & 0.0009 & -0.0573 & 0.0025 & 0.0013 \\
\hline ttaL1 & -0.0475 & -0.0077 & 0.0105 & 0.884 & 0.1992 & 0.0057 & -0.0105 & -0.0381 & -0.0198 & 0.3713 & -0.0316 & -0.008 \\
\hline tltaL2 & -0.0872 & -0.0311 & 0.0239 & 0.1887 & 0.5264 & 0.0073 & -0.0552 & -0.1461 & -0.0782 & 0.6047 & -0.146 & 0.002 \\
\hline ttaL 3 & -0.0861 & 0.006 & 0.0188 & 0.0832 & 0.563 & 0.0226 & -0.0661 & -0.0856 & -0.0672 & 0.2084 & -0.2199 & 0.0194 \\
\hline tltaL4 & -0.0585 & -0.0103 & 0.018 & 0.0675 & 0.7281 & -0.0745 & -0.0773 & -0.0231 & 0.0359 & 0.0386 & 0.0057 & 0.0153 \\
\hline tltaL5 & -0.0187 & 0.0112 & 0.0462 & 0.0765 & 0.8486 & 0.0697 & 0.0186 & -0.0304 & 0.2269 & -0.0355 & 0.0512 & -0.0106 \\
\hline tltaL6 & -0.0286 & -0.0041 & 0.0126 & 0.0464 & 0.5045 & 0.8081 & 0.0032 & -0.1149 & 0.0931 & -0.053 & 0.0212 & 0.0035 \\
\hline ttaL7 & -0.0457 & 0.0075 & -0.0005 & 0.0167 & 0.2562 & 0.5093 & -0.0097 & -0.2064 & 0.7432 & -0.0573 & -0.0158 & -0.0187 \\
\hline qaca & -0.0886 & 0.7233 & 0.0472 & 0.0145 & 0.0116 & 0.012 & 0.0355 & 0.0432 & 0.0017 & 0.1155 & -0.1109 & 0.0147 \\
\hline qacaL1 & -0.0601 & 0.8263 & 0.0357 & 0.0095 & 0.0141 & 0.0069 & 0.0498 & 0.0314 & -0.0045 & 0.1204 & -0.0145 & 0.0628 \\
\hline qacaL2 & -0.0552 & 0.8531 & -0.0339 & -0.0043 & -0.0282 & 0.0112 & 0.0385 & 0.0276 & -0.0095 & 0.0086 & -0.0624 & 0.0377 \\
\hline qacaL3 & -0.0776 & 0.8634 & 0.0091 & -0.0113 & -0.0093 & 0.0259 & 0.0059 & 0.0028 & -0.0048 & -0.0061 & -0.0246 & -0.015 \\
\hline qacaL4 & -0.0713 & 0.8476 & 0.0242 & -0.009 & 0.0007 & 0.0224 & -0.0203 & 0 & 0.0386 & 0.0058 & -0.0228 & 0.0261 \\
\hline qacaL5 & -0.0417 & 0.8455 & -0.024 & -0.0003 & -0.0115 & 0.01 & -0.0103 & -0.0253 & -0.0094 & -0.0518 & 0.0662 & -0.0155 \\
\hline qacaL6 & -0.0427 & 0.812 & 0.0217 & 0.0028 & 0.0314 & 0.0018 & -0.0294 & -0.0018 & 0.0572 & -0.0666 & 0.0545 & -0.0664 \\
\hline qacaL7 & -0.0613 & 0.7148 & -0.0083 & 0.0032 & -0.0171 & -0.0062 & -0.0333 & -0.0053 & -0.0116 & -0.0691 & 0.0479 & -0.0659 \\
\hline tetl & 0.7566 & -0.0613 & 0.1225 & -0.0268 & 0.0249 & 0.0095 & -0.0017 & 0.001 & -0.0136 & -0.0489 & 0.1049 & -0.199 \\
\hline tetlL1 & 0.7983 & -0.067 & 0.0867 & -0.0452 & -0.0019 & 0.0208 & -0.0353 & -0.0043 & -0.0162 & -0.0354 & 0.092 & -0.1849 \\
\hline tetlL2 2 & 0.8314 & -0.0766 & 0.0861 & -0.0436 & -0.028 & -0.003 & -0.0383 & 0.0129 & -0.0119 & -0.0178 & 0.1004 & -0.1711 \\
\hline telL3 & 0.8723 & -0.0717 & 0.0784 & -0.0173 & -0.0214 & -0.0035 & -0.0037 & 0.0041 & 0.0102 & 0.0005 & 0.0765 & -0.0656 \\
\hline tetlL4 4 & 0.8621 & -0.047 & 0.0827 & -0.0332 & -0.0393 & 0.0023 & -0.008 & -0.0127 & -0.0123 & -0.001 & -0.0411 & 0.0373 \\
\hline tetlL5 & 0.7735 & -0.0432 & 0.053 & -0.0274 & -0.0396 & 0.0195 & -0.0307 & 0.0774 & -0.0173 & 0.0405 & -0.0933 & 0.1622 \\
\hline tetlL6 & 0.7734 & -0.0797 & 0.0393 & 0.0282 & -0.0194 & -0.0321 & -0.0431 & 0.1197 & 0.0052 & 0.0234 & -0.097 & 0.2966 \\
\hline tetlL7 & 0.6923 & -0.0756 & 0.0755 & 0.0246 & -0.0299 & -0.0305 & -0.0293 & 0.1059 & -0.0074 & 0.0248 & -0.0869 & 0.3539 \\
\hline firmage & 0.2123 & -0.127 & -0.0376 & -0.061 & -0.1036 & 0.1005 & 0.1253 & 0.0901 & 0.0073 & -0.0531 & 0.0491 & -0.1607 \\
\hline avg_dir_age & 0.2007 & -0.0943 & 0.0254 & -0.033 & -0.0551 & 0.0766 & 0.0692 & 0.1808 & -0.0116 & -0.1972 & 0.0191 & -0.1537 \\
\hline $\mathrm{Nr}_{\text {r}}$ Female_Dir & -0.1474 & 0.0775 & -0.0596 & -0.0529 & -0.0491 & 0.0302 & 0.0502 & -0.0955 & 0.0462 & 0.1072 & 0.0542 & 0.0594 \\
\hline Total_Dir_Nr & 0.0421 & -0.0447 & -0.029 & -0.0086 & -0.025 & -0.0251 & -0.0226 & -0.0192 & 0.0027 & -0.0315 & 0.0145 & -0.0494 \\
\hline
\end{tabular}

